\title{
POPULAR AGENCY AND INTERESTS IN INDONESIA'S DEMOCRATIC TRANSITION AND CONSOLIDATION
}

\section{Edward Aspinall ${ }^{1}$}

A review of the last decade's worth of writing on Indonesia's democratic transition and consolidation reveals that a consensus seems to be emerging. At the risk of doing a disservice to many authors and the subtleties of their work, that consensus goes something like this. In the mid-1990s, the New Order regime, with Suharto at its apex, was very strong. There were tensions within the regime and sections of the middle classes were increasingly alienated from it, but these problems were second order; the authority of the regime was not seriously threatened. A managed succession to a postSuharto order, in which the basic elements of the regime would remain intact, was in the offing. That the regime fell in 1998 was not a result of popular mobilization per se. Instead, it was due to the exogenous shock of the 1997-98 economic crisis and tensions within the regime, triggered by the increasingly centralizing dynamic around Suharto, his children, and Suharto's inner circle. The economic shock set off protests that heightened political unrest, but these mobilizations were secondary to the economic crisis and the regime's internal tensions. The subsequent transition to electoral democracy was thus ersatz, or at least severely compromised. Forces representing genuine liberal reform or the interests of the lower classes were too poorly organized, or too dominated, to influence the regime change or character of the successor regime. This weakness of progressive forces was a legacy of the military's violent destruction

\footnotetext{
${ }^{1}$ I thank Eve Warburton for her excellent research assistance, and the participants in the Sydney University workshop who offered feedback; also, the Indonesia reviewers and the editors of this special issue, Michele Ford and Thomas Pepinsky; and Takuya Hasegawa for very useful feedback on earlier drafts of this article. I also thank the Australian Research Council which through two grants (DP098550404 and DP120103181) provided support to conduct part of the fieldwork upon which this article is based.
} 
of the PKI (Partai Komunis Indonesia, Indonesian Communist Party) and the rest of the Left in 1965-66, a legacy that continues to disable popular forces to this day. As a result, it was the very social and political forces that were nurtured by the New Order regime that were best placed to capture the institutions of formal democracy during and after the transition, and stamp their interests on policy formulation and implementation at all levels. Now, as a melancholy consequence of this confluence of factors, the oligarchs rule Indonesia, progressive forces are dispersed, and Indonesia suffers from an illiberal or stunted democracy as a result. ${ }^{2}$

There is much that is persuasive about this analysis, and I have myself articulated aspects of it in previous works. ${ }^{3}$ However, it is my contention in this essay that this approach, even if we adopt a class analytic framework, suffers from a major deficiency and misses critical dimensions of contemporary Indonesian politics. Accordingly, the article proceeds through three steps.

First, I propose that the conventional view writes popular agency too blithely out of the transition and the post-authoritarian dispensation. My view is that Indonesia's democratic transition was essentially driven from below, but that certain features of popular political forces-notably their organizational fragmentation-meant that key political institutions were thereafter captured, if not by former New Order incumbents, at least by former "semi-opponents" who had existed in an ambiguous relationship with state authority during the authoritarian period. ${ }^{4} \mathrm{I}$ am increasingly convinced, however, that many analysts moved too quickly to write off lower class political agency and influence in the post-New Order period as well.

\footnotetext{
${ }^{2}$ The picture of a standard narrative presented in this paragraph is, of course, a composite, and it is possible to find many works that argue against all or some aspects of it. Nevertheless, I contend that this narrative dominates scholarly interpretations of post-Suharto politics, either directly or indirectly (so that most authors writing on relevant topics at least feel compelled to respond to its key propositions). Key texts articulating the narrative are the major expositions of the oligarchy thesis discussed in this special issue, notably Richard Robison and Vedi R. Hadiz, Reorganising Power in Indonesia: The Politics of Oligarchy in an Age of Markets (London: RoutledgeCurzon, 2004); Vedi R. Hadiz, Localising Power in Post-Authoritarian Indonesia: A Southeast Asia Perspective (Stanford, CA: Stanford University Press, 2010); and Jeffrey Winters, Oligarchy (Cambridge: Cambridge University Press, 2011), but also other works by these authors as well as later elaborations by scholars who explicitly adopt their oligarchy framework (most recently Yuki Fukuoka, e.g., "Oligarchy and Democracy in Post-Suharto Indonesia," Political Studies Review 11,1 [2013]: 52-64). But key elements of the standard narrative, especially emphases on elite continuity in government office, exclusion of interests of subordinate groups in policymaking and implementation, and the detrimental effects of these phenomena on democratic quality, are found much more widely. Such arguments are, for example, pervasive among most early writings on post-Suharto local politics, and can be found in many chapters in major edited works on the topic, such as Edward Aspinall and Greg Fealy, Local Power and Politics in Indonesia: Democratisation and Decentralisation (Singapore: Institute for Southeast Asian Studies, 2002), Renegotiating Boundaries: Local Politics in Post-Suharto Indonesia, ed. Henk A. Schulte Nordholt and Gerry van Klinken (Leiden: KITLV Press, 2007); and Maribeth Erb and Priyambudi Sulistiyanto, Deepening Democracy in Indonesia? Direct Elections of Local Leaders (Pilkada) (Singapore: Institute of Southeast Asian Studies, 2009), as well as in full-length treatments of the topic, such as Nankyung Choi, Local Politics in Indonesia: Pathways to Power (London and New York, NY: Routledge, 2011).

${ }^{3}$ See especially Edward Aspinall, "The Irony of Success," Journal of Democracy 21,2 (2010): 20-34.

${ }^{4}$ Edward Aspinall, Opposing Suharto: Compromise, Resistance and Regime Change in Indonesia (Stanford, CA: Stanford University Press, 2005); "Semi-Opponents in Power: The Abdurrahman Wahid and Megawati Soekarnoputri Presidencies," in Indonesia: Soeharto's New Order and its Legacy: Essays in Honour of Harold Crouch, ed. Edward Aspinall and Greg Fealy (Canberra: ANU E-Press, 2010), pp. 119-34.
} 
Indeed, much writing on such matters in Indonesia is defined by an absence that lurks, as it were, just off stage. Many writers, whether explicitly or not, seek in Indonesia models of popular agency and representation derived from earlier historical epochs in other countries. Basically, authors have been searching for evidence of powerful, formalized, and permanent lower-class political parties and alliances of the sort that were associated with the extension of suffrage and democratic rights early in the European and Latin American democratic eras, especially in the form of a social democratic party based on a powerful labor union movement. ${ }^{5}$ Finding such forms absent, we conclude that popular agency is inconsequential and that Indonesian politics are entirely dominated by a reconstituted elite. Despite the descriptive accuracy of the account-there are no permanent, powerful, lower-class coalitions or parties-it misses many avenues for lower-class political agency and influence that have been open throughout the transition, and that are now experiencing greater and increasingly productive traffic. In short, observers have been looking for forms of agency and influence that do not exist, and missing those that do exist before our eyes.

Second, the article makes an initial attempt to identify key avenues for lower-class political influence that have emerged in post-authoritarian Indonesia. Two such avenues are proposed: fragmented activism and electoral populism. With regard to the first, the main reason observers have discounted the influence of organizations representing workers, farmers, and other subordinate groups is that such organizations have been splintered and have failed to build political parties with significant voter support. Here it is proposed that although fragmentation poses challenges to the capacity of such groups to wield influence, it does not mean that such influence has been absent or insignificant. In particular, political pressure exerted directly through mobilization occupies a prominent place in Indonesia's new political order, and policymakers are often responsive to it. Electoral populism locates the driving force for subaltern influence in the rise of competitive elections themselves, and the incentives they provide to contestants for political office to offer redistributive policies and other concessions to their lower class constituents. Much has been written about the dominance of forces nurtured in New Order circuits of power in postSuharto governments, but this emphasis misses how many politicians have endeavored to reinvent themselves by offering policy concessions to poor voters.

Third, to illustrate the preceding argument, the article explains how over the last half decade Indonesia has begun to see policy outcomes that do not fit with the narrative of a devastated Left and a democratic transition lacking organized representation of social interests. It would be possible to illustrate that point by analyzing a number of policy areas, but I focus on labor rights and healthcare, where we see significant advances and the continued maintenance of gains achieved early in the transition. I argue that changes in healthcare policy are primarily an outcome of electoral populism, while labor's continued prominence illustrates the ongoing power of fragmented activism.

\footnotetext{
${ }^{5}$ Richard Robison and Vedi Hadiz, for example, describe one critical weakness of Indonesian democracy as the absence of "a genuinely social democratic party ... with an agenda based on social justice," a prospect that they say is "currently implausible given the weakness of organized labor." See Reorganising Power, p. 259.
} 
As we shall see, my argument is not that scholars who emphasize political inequality in Indonesia, particularly proponents of the "oligarchy thesis," such as Richard Robison, Vedi Hadiz, and Jeffrey Winters, are entirely incorrect either in their underlying premises or in their diagnosis of Indonesian political power. With these authors, I accept the proposition that material inequality produces political inequality, including in democratic settings. I also do not question that there has been significant continuity in the composition of Indonesia's ruling elite, or that oligarchs are disproportionately powerful actors in the new regime. Such matters are beyond dispute. The more interesting questions are about the degree to which these oligarchs and other elites face challenges, and the degree to which other social interests, notably those of lower class groups, are also able to influence political outcomes. It is argued here that by focusing single-mindedly on the character and mechanisms of oligarchic dominance, structuralist scholars have lost sight of the bigger picture of contention among social groups that, it hardly needs to be said, has been central to materialist analyses of politics for over a century. My goal in this short piece is thus to place lower class groups and their interests back at the center of analysis of Indonesian politics. This suggests it is first important to review briefly the new structuralist orthodoxy, not simply about oligarchs and elites, but also about lower class political agency.

\section{Popular Politics and Regime Change in Indonesia}

The downplaying of the role of popular politics in analyses of post-authoritarian Indonesia has roots that can be traced back to analyses of Indonesia's democratic transition itself, if not before. The irony is that it has consistently been writers on the Left, especially those most influenced by Marxist and structuralist perspectives, who have been most dismissive of social agency. ${ }^{6}$ Perhaps in reaction against the optimism generated early in Indonesia's transition by liberal commentators, and wanting to demonstrate continuity in oligarchic power, their analyses emphasize internal conflict within the ruling bloc, exacerbated by the 1997 Asian financial crisis, as the main factor in Indonesia's transition. Space limitations prevent a thorough literature review, but there are a few samples worth consideration.

Among the starkest formulations is that advanced by Jeffrey Winters in his recent, masterly comparative book on oligarchy. Winters locates the trigger for regime change at the apex of the political and social structure rather than further down:

This breach among powerful actors at the top-which involved not just oligarchs, but also elements in the armed forces, party elites, leaders of Islamic mass organizations, and even members of Suharto's cabinet-created a vital political space for a mobilization of the last minute that could be reasonably secure against frontal retribution and thus gain enough momentum to overwhelm the regime.

He is equally clear in his assessment of popular forces and their capacity to bring about political change at this time:

\footnotetext{
${ }^{6}$ There are exceptions, such as Max Lane, Unfinished Nation: Indonesia Before and After Suharto (London: Verso, 2008); and A. E. Priyono, W. P. Samadhi, and O. Törnquist, ed., Making Democracy Meaningful: Problems and Options in Indonesia (Jakarta: Demos, 2007).

${ }^{7}$ Winters, Oligarchy, p. 178.
} 
[...] anger and resentment from below was a constant across the entire New Order. However, there are no indications that capacities and opportunities to organize civil society had improved significantly since the massacre of the PKI in 1965 and the shutting down of independent student organizations in the 1970s. There are no indications, moreover, that the regime had softened its approach in the 1990s to dissent, activism, organizing, and resistance from below [...] On the other side of the ledger, what did change dramatically was the degree of unity and coherence at the level of elites and oligarchs [...] By the onset of the 1997 financial crisis, [Suharto] had been abandoned. ${ }^{8}$

Such analyses by major scholars have now been taken up and reproduced in blunter form by more junior analysts who, presumably, did not witness the tumultuous street politics that accompanied the downfall of Suharto. It is hard to imagine how otherwise one could come to an assessment that "the fall of the Suharto regime took place even in the absence of an assertive civil society." ${ }^{\prime \prime}$

Such analyses systematically and unjustifiably diminish the role of societal organization and mobilization in the decade leading to the downfall of Suharto, and of social groups' critical influence in the regime change itself. Contrary to Winters's assessment, civil society capacities had increased steadily in the decade leading to Suharto's fall. Though they still faced formidable government repression, almost every sector of social activism (human rights, environmental activism, labor, the peasantry, to name a few) developed new organizations, forms of protest, communication networks, and other initiatives through the 1990s that had been entirely absent in earlier decades. Indonesia's pro-democracy civil society organizations were not as unified or forceful as in some authoritarian settings, such as apartheid South Africa or military-ruled South Korea, but the public sphere was certainly not denuded, and activist groups were far less cowed than in earlier decades.

It is also important to be clear about the relationship between societal mobilization and elite disunity in the events leading to the downfall of Suharto. Rather than seeking an explanation that attributes the collapse of the regime to a single factor, we need to diagnose carefully the interactions among the various competing forces. Even so, reconstruction of the chronology of events shows that, as Indonesia's political crisis began in late 1997, it was not elite opposition that triggered societal mobilization, but precisely the reverse. In the early 1990s, a significant fissure had opened within the regime, especially in the army. But by 1997, Suharto was again firmly in control: potential opponents had been excised from parliament, the cabinet, and other state organs, and the ruling elite had fallen in behind him once more (rather than having been abandoned by Suharto, as Winters would have it). No doubt, some senior regime figures were privately disgruntled with Suharto's continuing dominance, and many oligarchs were unhappy about the depredations of his children, but such discontent was contained, and entirely failed to find open political expression. What broke the political deadlock, and dramatically altered the calculus of senior regime leaders, was the wave of massive student and other demonstrations that began in February 1998,

\footnotetext{
${ }^{8}$ Ibid., p. 177.

${ }^{9}$ Yuki Fukuoka, 'Indonesia's 'Democratic Transition' Revisited: A Clientelist Model of Political Transition," Democratization, iFirst (2012): 1.
} 
remaking the political landscape and confronting regime leaders with new dilemmas (e.g., whether to authorize the security forces to shoot protestors). Accordingly, the critical breaks in the regime were initiated not by people who had been uncomfortable with Suharto's dominance, but by individuals who counted as his most ardent loyalists, such as Harmoko, the speaker of the House of Representatives. To be sure, after the mobilizations began, we saw the beginnings of what Alfred Stepan has called the "complex dialectic" between elite disunity and public protest, as students and others took heart from every sign of hesitation, vacillation, or disunity within the regime. ${ }^{10}$ There was thus ultimately a two-way interaction, but the forces that finally cracked open the regime were triggered more by popular mobilizations than elite friction. Indonesia's democratic transition was society-initiated. ${ }^{11}$

However, it was certainly not a society-dominated transition. Scholars such as Hadiz and Robison are correct in highlighting the organizational fragmentation and co-optation of large parts of civil society and the effects this had on the nature of the transition. Indonesia went into its transition while the opposition was in certain respects disorganized. In my own past work, I attributed the fragmentation and fluidity of organizational forms among opposition groups to the effects of New Order repression and the strategies opponents adopted to sidestep it. ${ }^{12}$ However, as this pattern of fragmentation has persisted into the post-authoritarian setting, I have come to see it as having other sources as well-including the influence of neoliberalism, and the persistence of patronage as a mode of organizing political life-and to see fragmentation as the defining feature of virtually all aspects of contemporary Indonesian social and political affairs, not just civil society. ${ }^{13}$ Whatever its source, the fact remains that the organizational, as opposed to the mobilizational, weaknesses of Indonesian pro-democracy groups allowed forces incubated under the New Order to reassert their leadership, so that the oligarchs and other elites captured the institutions of national and local state power, as has been exhaustively covered in the literature.

What about the role of lower class agency after the transition proper? Many structuralist writings on Indonesian politics in the post-Suharto period simply write popular forces out of the frame, without attempting to evaluate their influence seriously. Vedi Hadiz is one exception. In his assessment, "The main benefit of democratization for marginalized and formerly suppressed social groups is that they can now organize more freely and with less fear of direct repression from the state's security apparatus." ${ }^{14}$ Overall, however, he argues this "greater scope for political participation has resulted in little discernible empowerment of people who had already been marginalized under centralized authoritarianism." ${ }^{15}$ He elaborates:

\footnotetext{
${ }^{10}$ A. Stepan, Rethinking Military Politics: Brazil and the Southern Cone (Princeton, NJ: Princeton University Press, 1988), p. 39.

${ }^{11}$ A more complete version of the basic argument presented in this paragraph can be found in Aspinall, Opposing Suharto, especially chapter eight.

${ }^{12}$ Ibid., p. 240.

${ }^{13}$ Edward Aspinall, "A Nation in Fragments: Patronage and Neoliberalism in Contemporary Indonesia," Critical Asian Studies 45,1 (2013): 27-54.

${ }^{14}$ Hadiz, Localising Power, p. 144.

${ }^{15}$ Ibid.
} 
In a nutshell, the experience of organized labor in general and that of some peasant movements in the post-authoritarian period shows that democratisation and decentralisation have not produced an environment in which the interests of those who had been suppressed in the first place under authoritarian rule can now thrive. Although a certain amount of euphoria accompanied the fall of the New Order, workers and peasants have found that the institutions of decentralization and democracy-parties, local parliaments, and the likecontinue to be inhabited by the kinds of powerful interests with few organic links to peasant or labor movements. Instructively, similar to post-authoritarian Thailand and the Philippines, there is no major political party that claims to represent the interests of the working class or the peasantry. Indeed, those presiding over mutually competing local predatory coalitions have few reasons to set a course for social and political reforms entailing a substantial degree of redistribution of economic and political resources. Consequently, the new salience of electoral politics has been of only limited use to lower-class interests and social movements in post-authoritarian Indonesia. ${ }^{16}$

Hadiz's assessment is carefully qualified (e.g., "little discernible empowerment," rather than "no empowerment"; "limited use," rather than "no use"; and so on). In many respects, it is therefore difficult to disagree with it. But in seeking to assess the continuing influence of the fragmented and fractious political forces that transformed Indonesian politics in the final decade of Suharto's rule and drove the events leading to his regime's downfall, it is worth starting with three points.

First is the continuing ability of groups representing lower class interests to take advantage of the greater space afforded to them to organize and mobilize in defense of their interests, a point recognized by Hadiz. This has not been a trivial change. In the cacophony that is contemporary Indonesian democracy, as anyone who even glances at daily news reports would know, popular protest has become a well-established mode of political expression, despite the fragmented nature of the organizations responsible. ${ }^{17}$ Time and again, we see the policy goals and aspirations of business interests and other elite players being frustrated by protests or other forms of popular resistance, a point I illustrate in the next section.

Second, although formal politics have been dominated by oligarchs and former New Order powerbrokers, the influence of other forces and actors inside the formal political system is far from trivial. In fact, one of the problems for the Left in Indonesia is not that it is isolated and oppressed (as the standard, still-to-survive-from-thecataclysm-of-1965 narrative would have it), but that its members face too many pathways for entry and absorption into mainstream politics, preventing their consolidation as a distinctive oppositional force ${ }^{18}$ With official politics dominated by populist and economic nationalist discourse, the boundary between official politics and

\footnotetext{
${ }^{16}$ Ibid., p. 160.

${ }^{17}$ One recent compilation of reports of protests from the national media, put together by Anom Astika, records a total of 1,114 demonstrations for the period January 5-25, 2013: https: / www.evernote.com/ shard/s208/sh/54ed5263-919c-4f14-a164-a6c8dacaf964/7f6c9d741bb739bfa3666a92c681ce54. Accessed April 15, 2013.

${ }^{18}$ This point is developed at greater length in Edward Aspinall, "Still an Age of Activism," Inside Indonesia 107 (2012), http: / / www.insideindonesia.org/weekly-articles/still-an-age-of-activism.
} 
the world of activism is highly porous. As a result, the failure of NGOs and left-wing social movements to form their own parties does not mean such forces are alienated from formal politics. On the contrary, over the last decade most mainstream political parties have been eager to recruit former activists and use their networking skills and populist credibility for the party's benefit. Both the national parliament and regional legislatures contain many former activists. As Marcus Mietzner has demonstrated, while former activists-turned-politicians have not been able to dominate Indonesia's parliament, their role has been significant and, often cooperating with NGO lobbyists and protestors outside parliament, they have been able to promote legislative change in a host of areas, such as military reform, women's right, and labor law. ${ }^{19}$ Thus, despite the image of an unreconstructed New Order elite still holding sway in the literature, the real picture is more complex, with many networks and clusters of actors that connect that ruling elite with activist groups and coalitions, providing not only mechanisms for co-optation from above, but also conduits for policy influence from below.

Third, we should not let the standard narrative of continuity in Indonesia's oligarchy and ruling elite make us miss the extreme internal heterogeneity, fragmentation, and competitiveness of that elite. Admittedly, the oligarch theorists concede this point in the abstract, but they tend to overlook the many opportunities elite fragmentation has afforded in practice to social movements and other forces to extract policy concessions from the new ruling caste. One of the defining features of the post-Suharto order is elite competition, with a highly varied array of bureaucrats, businesspeople, brokers, and others constantly rising to the surface of district, provincial, and national politics, forever remaking their political alliances as they shoulder each other aside in the competition for positions of political authority and control over resources. This fractiousness, ultimately a product of the decentered organization of patronage and of the new politics of electoral competition, is demonstrated by such phenomena as the continued internal conflict, splintering and remaking of political parties at the center, and the constant churning and replacement of local government leaders in the regions. ${ }^{20}$ Such elite competition means that electoral strategies produce at least some elites who try to strengthen themselves politically by reaching out to poor constituents via political networks or by offering concessions, as an increasing number of accounts of local electoral dynamics reveal. ${ }^{21}$ In short, the fragmentation and competitiveness of the ruling elite multiplies the opportunities for groups representing more marginal social interests to engage in strategic cooperation with, and wring concessions from, elite politicians, even if the compromises and coalitions so formed rarely take stable or institutionalized form.

As a result of these three factors-the liberalization of politics and resulting flourishing of mobilization, the penetration of official politics by groups linked to social movements, and intra-elite competition-Indonesian democracy is beginning to

\footnotetext{
${ }^{19}$ Marcus Mietzner, "Fighting the Hellhounds: Pro-Democracy Activists and Party Politics in Post-Suharto Indonesia," Journal of Contemporary Asia 43,1 (2013): 28-50.

${ }^{20}$ Aspinall, "A Nation in Fragments." Note that this internal conflict within the oligarchy, and between oligarchs and other elites, is also a critical component of Winters's account in Oligarchy.

${ }^{21}$ See, for example, Ryan Tans, Mobilizing Resources, Building Coalitions: Local Power in Indonesia (Honolulu, HI: East-West Center, Policy Studies No. 64, 2012).
} 
deliver not simply greater space for organization, but also some social gains for the poor. The following pages illustrate this basic proposition by way of two examples, each representing one of the two main mechanisms of non-elite political leverage identified at the outset of this paper: fragmented activism and electoral populism. These examples do not demonstrate that oligarchs are insignificant in politics. But they do suggest that mono-tonal characterizations of Indonesian politics as being simply about elite capture of state power need to be qualified significantly.

\section{Fragmented Activism and the Politics of Labor}

Organized labor is the political force that, arguably, is seen as being the most marginalized in post-authoritarian Indonesia. Its role in the political transition itself, in contrast to groups like students or the urban poor, was minimal. ${ }^{22}$ As numerous authors have pointed out, the rapid dismantling of many of the most restrictive antiunion laws and regulations in the aftermath of the collapse of the regime was followed by a flourishing, but also a fragmentation, of labor activism. ${ }^{23}$ Two years after the collapse of the Suharto regime, twenty-four national unions and more than ten thousand enterprise unions had registered with the government. ${ }^{24} \mathrm{~A}$ couple of years later, there were more than sixty union federations and three significant confederations, and by 2012 six confederations and ninety-one federations. ${ }^{25}$ By late 2012, labor activists themselves were lamenting the "localism and sectoralism" that defines their movement: "lots of trade unions are formed at the level of just one city ... or at the level of just one factory or company." ${ }^{26}$ These have not been propitious circumstances for the rise of labor as a powerful political force. Attempts to form electorally successful labor-based political parties and to seek governmental power through workers' support have failed. Yet, for all its apparent marginalization, labor exercises surprising leverage via industrial and street power, and through informal linkages to electoral politics.

Take, for example, national regulations. In the view of one observer, the postSuharto period has seen a "major shift in government policy towards greater support of labour rights and standards." ${ }^{27}$ This was partly related to the appointment of several ministers of manpower who had backgrounds as former leaders of the corporatist

\footnotetext{
${ }^{22}$ Edward Aspinall, "Democratisation, the Working Class, and the Indonesian Crisis," Review of Indonesian and Malaysian Affairs 33,2 (1999): 1-32.

${ }^{23}$ Teri L Caraway, "Protective Repression, International Pressure, and Institutional Design: Explaining Labor Reform in Indonesia," Studies in Comparative International Development 39,3 (2004): 28-49; M. Ford, Workers and Intellectuals: NGOs, Trade Unions, and the Indonesian Labour Movement (Singapore: Singapore University Press, 2009).

${ }^{24}$ Ford, Workers and Intellectuals, p. 161.

${ }^{25}$ Chris Manning, "The Political Economy of Reform: Labour after Soeharto," in Soeharto's New Order and Its Legacy: Essays in Honour of Harold Crouch, ed. Edward Aspinall and Greg Fealy (Canberra: ANU E Press, 2010), p. 157; and "Gerakan Buruh Kian Mandiri," Kompas, December 3, 2012.

${ }^{26}$ Interview with Dita Indah Sari, Jakarta, September 14, 2011. Note, however, that according to Benny Juliawan, the picture of fragmentation is often exaggerated: "As a matter of fact, there are only three confederations, whose combined membership in 2008 covered almost 80 percent of all union members." Benedictus (Benny) Hari Juliawan, "Playing Politics: Labour Movements in Post-Authoritarian Indonesia" (PhD Dissertation, Oxford University, 2011), p. 152.

${ }^{27}$ Manning, "Political Economy of Reform," p. 158
} 
labor organization of the New Order. Particularly important was the role of the Suharto-era SPSI (Serikat Pekerja Seluruh Indonesia, All Indonesia Union of Workers) leader Jacob Nuwa Wea as minister under Megawati Soekarnoputri (Nuwa Wea retained his SPSI presidency while serving as manpower minister). Under his stewardship, and demonstrating the importance of highlighting political variation among leaders "incubated" under the New Order, Law No. 13 of 2003 was passed:

This law covers a wide range of labour protection issues, bringing together previous legislation scattered in a range of Ministerial and Presidential Decrees and government laws, as well as setting new standards in areas such as protection of female workers and procedures and compensation for layoffs and dismissals. $^{28}$

Though the law was not an unqualified victory for trade unions (for example, unionists subsequently criticized it for allowing outsourcing of labor services), in certain respects it is significantly pro-labor. In particular, the provisions on severance pay, which set rates at fifteen to twenty months' salary for workers with five to ten years of employment, were much higher than in most countries. ${ }^{29}$

The pro-labor aspects of the law were a result both of labor's mobilizational efforts and its policy lobbying, and of the greater openness of elements within the new ruling elite to labor demands. When the plans for a new labor bill were first announced, there were massive protests at the national parliament, or DPR (Dewan Perwakilan Rakyat, People's Representative Assembly), in September 2002, leading to the bill's postponement, "the first time since the controversy around the 1974 Marriage Law that a social group had forced the parliament to postpone the promulgation of a law." ${ }^{30}$ Members of the relevant parliamentary commission (especially several from the PDI-P, Partai Demokrasi Indonesia-Perjuangan, the Indonesian Democratic Party of Struggle) subsequently invited a number of worker representatives to contribute their input to the law's design. ${ }^{31}$ Minister Nuwa Wea also personally intervened at a critical moment in the negotiations, securing for workers the very generous severance pay conditions that later caused so much criticism by employers. ${ }^{32}$

In addition to the significant input that organized labor had in the formulation of this legal framework, it is worth noting labor's mobilizational power in defending those aspects it saw as beneficial to its interests. In the mid-2000s, employer organizations and Yudhoyono's first manpower minister, Fahmi Idris, called for revisions to the law, bemoaning in particular the severance pay conditions it mandated, saying that these were a major disincentive to investment. ${ }^{33}$ When the government sent amendments to the DPR, a major wave of worker mobilizations began. There were

\footnotetext{
${ }^{2 s}$ Ibid., p. 158.

${ }^{29}$ Ibid, p. 160, fn. 14.

${ }^{30}$ Jafar Suryomenggolo, "Labour, Politics, and the Law: A Legal-Political Analysis of Indonesia's Labour Law Reform Program," Labour and Management in Development 9 (2008): 4.

${ }^{31}$ Ibid, pp. 4-6. See also Teri L. Caraway, "Explaining the Dominance of Legacy Unions in New Democracies: Comparative Insights from Indonesia," Comparative Political Studies 41,10 (2008): 1371-97.

${ }^{32}$ Dinna Wisnu, "Governing Social Security: Economic Crisis and Reform in Indonesia, the Philippines and Singapore" (PhD dissertation, Ohio State University, 2007), p. 193.

33 "Labor Factor Seen as Hindering FDI," The Jakarta Post, July 15, 2005.
} 
massive strikes on May Day 2005, and also a huge rally that ended with violent clashes outside the DPR building in Jakarta. Notably, as these protests gained steam, parts of the official political establishment expressed support, keen to burnish their populist image. PDI-P and PKS (Partai Keadilan Sejahtera, Prosperous Justice Party) leaders were particularly vocal in endorsing the demands of protesting workers, and eventually the DPR stated it would refuse to consider the amendments. ${ }^{34}$ Finally, the government backed down and shelved the revisions. As Chris Manning concludes, "Fear of union and wider community backlash against any reforms which appeared to be against the interests of labour ... meant that reforms aimed at reducing hiring costs and rigidity in employment and wages were too sensitive a subject for political leaders." ${ }^{35}$

This capacity for influential street politics is based on what has become a deeply entrenched subculture of protest action among sections of labor at the local level. According to Benny Juliawan, although the "plethora of alliances, coalitions, and forums or fronts that exist among small trade unions and their overlapping constituencies can look chaotic to an unsuspecting observer, fragmentation is only half of the story." ${ }^{36}$ Labor unions, NGOs, and other groups, he argues, have a great capacity for alliance building and cooperative action, even though "tactical alliances [often] last only for one particular collective action." ${ }^{37}$ This pattern of both fragmentation and propensity to alliance-building is itself a legacy of the last decade of the authoritarian period, when the combination arose as part of an attempt to minimize repression while maximizing political effect. ${ }^{38}$ Much of the new labor activism is, by necessity, extremely fragmented, occurring in a single factory, focusing on wage rises in one particular district, or otherwise taking place at a local level. Nevertheless, Juliawan sees in the proliferation of local street protests by workers the embryo of an Indonesian "movement society," in which the representation of claims by social movements has become normalized. ${ }^{39}$

Moreover, in recent years, organized labor has increasingly taken the political offensive. Another wave of major mobilizations occurred through 2011 and 2012, particularly in the industrial heartland of Bekasi to the east of Jakarta, but also in other areas. ${ }^{40}$ While some of these protests focused on traditional issues, such as wages, others were more proactive, for example, demanding the end of outsourcing and contract work. Major labor mobilizations have also occurred in support of social issues, such as to defend fuel subsidies and promote social security reform. Unions have pioneered increasingly militant forms of action, including general rather than single factory-based strikes, blockades of roads leading in and out of industrial estates, and

\footnotetext{
34 "House Tells SBY to Drop Labor Law Revisions," The Jakarta Post, June 5, 2006.

${ }^{35}$ Manning, "Political Economy of Reform," p. 163.

${ }^{36}$ Juliawan, "Playing Politics," p. 155.

${ }^{37}$ Ibid.

${ }^{38}$ See, for example, Aspinall, Opposing Suharto, pp. 97, 132.

${ }^{39}$ Benny Juliawan, "Street-level Politics: Labour Protests in Post-authoritarian Indonesia," Journal of Contemporary Asia 41,3 (2011): 367.

${ }^{40}$ See Teri L. Caraway and Michele Ford, "Labor Unions and Electoral Contests in Democratic Indonesia," paper presented at "Beyond Oligarchy? Critical Exchanges on Accountability and Representation in Indonesia," the University of Sydney, December 14-15, 2012.
} 
the practice of "sweeping," in which militant workers invade factories and enable or force those workers inside to join them. The recent wave of mobilization, which included a national strike of two million workers in early October 2012, is the greatest in modern Indonesian history and reflects remarkable confidence on the part of labor. In 2012, labor militancy became so widespread that spokespersons of the Employers' Association, APINDO (Asosiasi Pengusaha Indonesia), spoke of it as representing a major impediment to investment, said that companies were considering relocating overseas, and threatened a production strike. ${ }^{41}$

Even organized labor's marginalization from electoral politics may be changing. Some sectors of the workers' movement formed labor parties early in Indonesia's democratic transition, but recorded poor results. At the same time, some of the more effective and militant labor organizations, such as the metalworkers' federation, FSPMI (Federasi Serikat Pekerja Metal Indonesi), abstained from the electoral arena, reflecting a broader activist hostility toward representational politics in the early transition. ${ }^{42}$ Yet, as Michele Ford and Teri Caraway note, the mood began to change as Indonesian democracy consolidated, and as major parties recognized the mobilizational power of labor. ${ }^{43}$ Ford explains that there have been "substantial and repeated overtures made to prominent labor activists in the industrial heartlands of Java and Sumatra, which began shortly after the 2004 general election and subsequently strengthened in the lead-up to the electoral contests of 2009." ${ }^{44}$ Few successes have been achieved by the ensuing coalitions, but they point to deeper and less formal interactions among organized labor and electoral politics. Thus, in many other cases, labor activists work as members of tim sukses (campaign teams) of non-labor candidates, wresting concessions from them in the process; other candidates in local and national elections sign "political contracts" with labor groups. ${ }^{45}$ In the 2009 presidential election, for example, "the Megawati-Prabowo pair promised to institute May Day as a national holiday and to abolish contract work, the Jusuf Kalla-Wiranto pair pledged to abolish contract work and outsourcing practices." ${ }^{40}$

Although such flirtations with electoral politics have not translated into embedded institutional power for labor, the desire of mainstream politicians to court workers' support has nevertheless produced concrete gains. In particular, the fact that local governments now have a role in setting regional minimum wages has made officials in industrial regions eager to court labor support, especially in periods leading to elections. Thus, for example, the West Java government, in a year leading to a pilkada (direct local elections), authorized a 16 percent minimum wage increase in Bekasi, in excess of the 10 percent recommended by the National Wages council and prompting

\footnotetext{
${ }^{41}$ See, for example, "Pengusaha Ancam Mogok Produksi," Koran Tempo, November 6, 2012.

${ }^{12}$ Michele Ford, "Towards Issue-Based Politics: Trade Unions and Elections in Batam, 2004-2010," paper presented at "Decentralization and Democratization in Southeast Asia," Freiburg University, June 15-17. 2011 , p. 8 .

${ }^{43}$ Caraway and Ford, "Labor Unions and Electoral Contests."

${ }^{44}$ Ford, "Towards Issue-Based Politics," p. 3.

"Juliawan, "Playing Politics," p. 264.

${ }^{46}$ Ibid., pp. 264-65.
} 
the employers' association to sue. ${ }^{47}$ In Jakarta in 2011, approaching another election year, Governor Fauzi Bowo raised the minimum wage for Jakarta by 15 percent, three times higher than the local inflation rate and twice the recommendation of the independent mediation body. ${ }^{48}$ His successor, Joko Widodo, increased the minimum wage by 43 percent, amidst a rash of large wage increases in other regions, earning the condemnation of employers' organizations for doing so. ${ }^{49}$ Such increases have produced a dramatic increase in real wages, even if labor costs are still far less than in some relevant comparison regions, such as Southern China. The increases certainly have been unwelcome to, and condemned by, employers, many of whom have sought exemptions.

Indonesia has not seen a radical expansion of the political power of labor. It has not embarked on the path blazed by early industrializing countries one hundred years ago, with large labor-based parties or electoral coalitions able to wrest governmental power directly from their class rivals. But we do not need to set the bar so high in assessing the changing balance of class forces in post-Suharto Indonesia. Organized labor has made gains that have gone beyond greater freedom of organization and expression. Democratization has generated significant space to mobilize for improvements in terms of wages, workplace conditions, and other social benefits, and labor has recorded many achievements in this sphere. Labor's influence has been gained primarily in two ways: first, by the street power it has won, enabled by democratic space to organize and, second, by informal interactions with the world of formal politics. And this increasing influence has been achieved despite the fragmentation of labor organizations.

We could make similar analyses of other sectors where, despite fragmented organizational patterns and uneven progress, social and material gains have been recorded by low-class groups. For example, in many parts of the country disenfranchised peasants achieved significant victories in the immediate aftermath of reformasi. In places where land disputes between local communities and state agencies or private developers had stretched for years, or even decades, farmers occupied hundreds of thousands of hectares of land, with these informal occupations leading to permanent victories in many places in the form of title to the land being subsequently granted to the occupiers. Business groups and officials frequently complain vociferously about the difficulties and expense of acquiring land for their activities as a result of residents' protests and recalcitrance, and the country is littered with failed projects where land acquisition has come to nothing. ${ }^{50}$ This is a critical change from the

\footnotetext{
47 "Labor Row Rages on as Court Decides to Hear Apindo," Jakarta Post, January 25, 2012; and "Mekanisme Pengupahan Dilanggar Elite Lokal," Kompas, February 3, 2012.

${ }^{48}$ Liam Gammon, "Voters, Elites, and Urban Planning in an Asian Megacity: A Case Study of the 2012 Gubernatorial Elections in Jakarta" (honors thesis, Australian National University, 2012), p. 45. See also "Upah Minimum Provinsi: Pekerja dan Pengusaha Kaget Kenaikan Upah," Kompas, November 26, 2010.

${ }^{49}$ See, for example, "UMP Naik Sofjan Salahkan Jokowi," Koran Sindo, April 9, 2013. These increases were not the first time Jakarta had seen large wage rises linked to elections: in 2001, another election year (though at that time governors were still elected by provincial legislatures), Governor Sutiyoso raised the minimum wage by 40 percent, the largest such increase in Indonesian history up to that time; see Manning, "Political Economy of Reform," p. 10.

${ }^{50}$ For one recent example, see "Land Acquisition a Big Problem for Infrastructure Projects," Jakarta Post, December 3, 2012.
} 
Suharto period, when conflicts over land expropriation invariably ended with victory for the developers and when compensation to the losers was often extremely meager, if given at all. In a few cases, such as parts of the province of Bengkulu, or the district of Batang, in Central Java, farmer groups have been able to achieve greater electoral success than their equivalents in the labor movement, wresting significant influence in local legislatures and executive governments. ${ }^{51}$

As with organized labor, it would be possible to point to many exceptions and to list numerous qualifications. The patterns are often messy and there are many forms of bargaining and compromise between lower class constituents and the traditional elites who occupy political office. Brokerage and clientelism more often mediate connections between the two groups than do social movements and political mobilization. This, in many ways, is the point: social struggles and advances are now happening in highly fragmented ways, reflecting the patterns of splintered activism that constitute contemporary Indonesia's social-movement landscape, and its enmeshment in fractured clientelistic and electoral politics. Such a fragmented pattern may not constitute a decisive shift in the balance of class forces, but it does suggest that significant social gains are possible, a topic we turn to now.

\section{Electoral Populism and the Politics of Health}

Since about 2005, a near-revolutionary shift in the nature of Indonesian politics has taken place, though few observers have noticed it. During early post-Suharto elections, many analysts derided the empty populism of the campaigning: parties and candidates, it was all but universally agreed, offered little to the electorate except vague slogans. Programmatic politics were virtually absent and voters could expect little concrete improvement in their life situations from voting for particular candidates or parties. Such was the conventional assessment.

This situation has changed significantly. Throughout Indonesia, candidates for political office, in both national elections and especially local ones, are responding to electoral incentives and competing with one another to offer increasingly elaborate and generous social programs. In particular, promises of free and improved healthcare and education have become all but ubiquitous in local executive government head elections. At the national level, too, successive governments have offered increasingly ambitious and generous social programs. True, many of these promises are not implemented fully after the votes are counted, but it is impossible to deny the new political salience of social welfare in Indonesian politics. The tentative beginnings of an Indonesian welfare state are becoming visible.

The remainder of this section examines the rise of social welfare in Indonesian politics by focusing on healthcare. The recent history of the expansion of public healthcare programs in Indonesia is complex, and begins with the financial crisis of 1997-98, when the central government, with assistance from the World Bank, established a "Social Safety Net" that included healthcare cards that granted free access to health services for the poor, and increased funds for those services. A series of new

51 One excellent overview is Dianto Bachriadi, "Between Discourse and Action: Agrarian Reform and Rural Social Movements in Indonesia, Post-1965" (PhD dissertation, Flinders University, 2011). 
schemes was introduced under successive governments, culminating in 2008 with a scheme called Jamkesmas (Jaminan Kesehatan Masyarakat, Community Health Insurance). Jamkesmas provides "basic healthcare in public health clinics and hospital inpatient care" for the poor and informal sector employees. ${ }^{52}$ By 2012 , the scheme was covering approximately 76.4 million beneficiaries, with a budget allocation of Rp 7.29 trillion (approx. US\$750 million). ${ }^{53}$

Framing these schemes and other measures, the national parliament passed two laws setting out an ambitious agenda to provide universal social insurance: Law No. 40 of 2004, on the National Social Security System; and Law No. 24 of 2011, on the National Social Security System Provider Bodies. The first of these laws established a plan to provide universal social insurance that would cover healthcare, workplace accidents, death, old-age care, and pensions; the second law provides the framework for the institutions that will administer the scheme. Under the system, insurance for private and public sector employees will be covered by mandatory contributions shared between employers and employees; contributions will for the first time also be made obligatory for informal sector workers. The government will pay the premiums on behalf of the poor. The scheme will begin to be implemented in 2014 and is expected to be fully operational by 2019. By this time, social insurance coverage will have become universal.

Overall, welfare policies have had an important, but seldom remarked upon, role in national politics. Before the 2009 election, the government invested heavily in various social programs; in the aftermath, President Susilo Bambang Yudhoyono's poll figures improved significantly. According to one assessment:

[I]t was the introduction of massive cash programs for the poor that triggered Yudhoyono's meteoric rise from electoral underdog to almost unassailable frontrunner. Between June 2008 and April 2009, the government spent approximately US $\$ 2$ billion on compensation payments for increased fuel prices, schooling allowances, and micro-credit programs. ${ }^{54}$

In healthcare, it has, however, been at the local level where most of the political action has taken place. Decentralization reforms passed responsibility for managing public health to Indonesia's district governments. Beginning with a few celebrated cases, such as the Jaminan Kesehatan Jembrana, in Jembrana, Bali, over the last decade, local health insurance and protection schemes have spread like wildfire across Indonesia's regions, such that there are at least six at the provincial level and hundreds in the districts, with 2011 national data suggesting that 32 million persons were covered by such schemes. ${ }^{55}$

\footnotetext{
${ }^{52}$ Robert Sparrow, Asep Suryahadi, and Wenefrida Widyanti, Social Health Insurance for the Poor: Targeting and Impact of Indonesia's Askeskin Program (Jakarta: SMERU Working Paper, 2010), p. i.

${ }^{53}$ Elly Burhaini Faizal, "Government to Spend Rp 25 trillion for BPJS," The Jakarta Post, August 2, 2012.

${ }^{54}$ Marcus Mietzner, "Indonesia's 2009 Elections: Populism, Dynasties, and the Consolidation of the Party System," an analysis for Lowy Institute for International Policy (May 2009), p. 4.

${ }^{55}$ Profil Data Kesehatan Indonesia 2011 (Jakarta: Kementerian Kesehatan Republik Indonesia, 2012), table 5.34. A recent survey conducted by the SMERU Research Institute found that 245 of 262 districts that provided information had some sort of local health financing scheme; see SMERU, "District Health Care Financing Study: Descriptive Statistics and Initial Results," PowerPoint presentation, 2012.
} 
There is much variation in the coverage these schemes provide. Some of the most generous, especially those in cashed-up resource-rich regions, such as the province of Aceh or the district of Musi Banyuasin, in South Sumatra, provide universal coverage, with access to all manner of healthcare services for all residents. These schemes cover a fuller range of treatments and pay for longer periods of care than what is provided under Jamkesmas. In Aceh, for example, under Jaminan Kesehatan Aceh (JKA, Aceh Health Insurance program), there is no limit on the variety of illnesses that can be treated. Patients who require care that cannot be provided in Aceh-neurological or heart surgery, for example-can be flown to hospitals in Jakarta, in chartered airplanes, and may be accompanied by medical staff if necessary. In Aceh, the scheme is very popular, and its introduction produced a sudden spike in the number of patients using the public health system, such that demand outpaced supply, and many patients had to sleep on hospital floors due to a shortage of beds. ${ }^{56}$

Most schemes provide less comprehensive coverage than does Aceh's. For instance, in Solo, a "gold card" for poor residents does not limit the amount of care provided; a silver card is provided to "almost poor" residents whose benefits are capped at Rp. 2 million per year. ${ }^{57}$ Other schemes, especially in poor regions, are even more restricted. For example, in Central Lombok, the newly elected bupati did not promise comprehensive coverage, but instead promised that there would be free maternity coverage ${ }^{58}$ The fact that candidates even in resource-poor regions promise such services during elections, however, points to how widespread the model is becoming, and to the power of electoral competition to drive policy change.

How are we to explain healthcare's newfound political salience? What does it say about the balance of social power in Indonesia's new democracy? Guidance can be found in studies of other cases in the region. In examining new healthcare regimes in South Korea and Taiwan, Joseph Wong has persuasively argued that conventional structural explanations fail to account for the emergence of wide-ranging social programs in both countries since the 1980s. He discounts class mobilization theories that see welfare programs as a product of the "balance of class power." ${ }^{59}$ Instead, Wong argues, the key factor was democratization itself, whereby universalization of healthcare was a "strategic response to the new logic of political competition," especially by incumbents. ${ }^{60} \mathrm{~A}$ similar dynamic has been apparent in Indonesia, though the time lag between democratic breakthrough and universalization of healthcare has been longer, and it is more challenging to establish social protection in a country that is poorer than either Taiwan or South Korea was at the time of their transitions. In Indonesia, as in South Korea and Taiwan, the spread of new social welfare schemes is

\footnotetext{
56 "RSU di Aceh Booming. Pasien JKA Tidur di Lantai," Serambi Indonesia, September 30, 2009. The latest province to experience such an upsurge in patient demand has been Jakarta, after the introduction in late November 2012 of a free healthcare scheme by the new governor, Joko Widodo. See, for example, "Free Healthcare Overwhelms Depok, Jakarta," Jakarta Post, February 23, 2013.

${ }^{57}$ Interview with Asep Suryahadi, SMERU Research Institute, September 12, 2011.

${ }^{58}$ http:/ / lomboktengahkab.go.id/index.php?option=com_content\&view=article\&id=531:7-komitmenbupati-loteng-segera-dilaksanakan\&catid=1:berita\&Itemid $=36$, accessed March 1, 2013.

${ }^{59}$ J. Wong, Healthy Democracies: Welfare Politics in Taizan and South Korea (Ithaca, NY: Cornell University Press, 2004), p. 11.

${ }^{60}$ Ibid., p. 15.
} 
not dependent on structural coalitions among labor and other social groups, though there was significant mobilization by labor unions and NGOs in favor of the passage of the national social security legislation. ${ }^{61}$ Instead, welfare schemes have been promoted by mainstream, elite politicians, eager to present themselves as champions of social reform for electoral gain.

This logic is clearest at the local level, where access to affordable healthcare has been promoted by the new governing elite in the regions, the very force identified in much of the literature as representing social exclusion and oligarchic domination. Rosser, Wilson, and Sulistiyanto argue that the bupati who have adopted free education and healthcare policies have tended to be those who are "relatively autonomous of predatory interests." ${ }^{62}$ Adopting policies that appeal to the poor, they argue, allows such politicians to bolster their chances of reelection and confront potentially hostile legislatures. Accordingly, some of the bupati, mayors, and governors who have initiated new healthcare schemes have had backgrounds in public health, links with NGOs, or some other aspect in their personal biography that inclines them toward universalizing healthcare. The lead example here is Gede Winasa, the bupati of Jembrana, Bali, and the best-known pioneer of local health insurance in Indonesia. He had worked in the health system for many years as a dentist, academic, and civil servant, but also had a history of political activism, notably in the post-1998 movement to abolish the caste system in Bali. ${ }^{63}$ The governor of Aceh responsible for the JKA scheme, Irwandi Yusuf, was not only a former separatist rebel, he was also a university-trained veterinarian sympathetic to the ideas of European social democracy.

While the personal qualities of leaders may have been important in the early take up of local healthcare schemes, in recent years it appears that this policy strategy has become modular, with programs being copied and adapted from region to region with great rapidity and variety. Indeed, some of the politicians identified with the new policy approach are the epitome of old-style politics, being local bosses longentrenched in the bureaucracy and adept at playing patronage politics. Among these are Alex Noerdin, the former bupati of Musi Banyuasin and then governor of South Sumatra; and Fauzi Bowo, governor of Jakarta in 2007-12. In Jakarta, Fauzi, a notorious old-style patronage politician, launched an 800 billion rupiah "health card" program, which provided free healthcare up to 100 million rupiah per person in 2012, which happened to be an election year in Jakarta. ${ }^{64}$ Fauzi made healthcare and education policies central to his bid to win re-election. Alex Noerdin, who also ran in the Jakarta election, campaigned on his success in providing free healthcare and education in South Sumatra. ${ }^{65}$ The winner was Joko Widodo, the mayor of Solo, who owed part of

\footnotetext{
${ }^{61}$ Rachelle Peta Cole, "Coalescing for Change: Opportunities, Resources, Tactics, and Indonesia's 2010-11 Social Security Campaign" (honors thesis, University of Sydney, 2012).

${ }^{62}$ Andrew Rosser, Ian Wilson, and Priyambudi Sulistiyanto, "Leaders, Elites, and Coalitions: The Politics of Free Public Services in Decentralised Indonesia," Developmental Leadership Program Research Paper 16, 2011, p. 15.

${ }^{63}$ Ibid., p. 19.

64 "Kartu Sehat: Tahap Pertama Diberikan di 6 Wilayah Kumuh," Kompas, November 1, 2012.

${ }^{65}$ See, for example, "Fauzi Launches Populist Programs as Runoff Nears," The Jakarta Post, August 2, 2012; and "Free Healthcare, Education Not Essential," The Jakarta Post, July 4, 2012.
} 
his own populist appeal to the effective healthcare program he had introduced while running the administration of that central Javanese city.

The centrality of social welfare to the 2012 Jakarta election campaign is just one example of a broader pattern of electoral competition driving policy change throughout Indonesia's regions. Many local elections have become virtual bidding wars, in which rival politicians offer ever more generous health insurance schemes (alongside other inducements) to entice voters. At the national level, too, it is all but impossible to identify clear differences in party positions over the National Social Security System; instead, there is virtual unanimity of support for the basic outline. In short, democratization has created strong incentives for all political players to design policies that will appeal to the poor, and over the last half decade or so we have seen adroit politicians adjusting their policies accordingly. Electoral populism has become a key vector through which social welfare policies are being introduced.

It would be naïve to suggest that these changes have ushered in an era of high quality or universal healthcare for Indonesia's poor. The level of investment made by Indonesia in public healthcare remains low even by Southeast Asian standards, though it is rising rapidly. The quality of the services that are provided to poor people is appallingly bad, and certainly miserable in comparison to those provided under universal schemes in rich countries. Staff absenteeism and poor training, misdiagnosis, inadequate treatments and equipment, and other shortcomings are all rampant. ${ }^{66}$ Moreover, even ostensibly "free" healthcare often ends up costing users. As Andrew Rosser has cogently argued, illegal fees remain pervasive in healthcare because of the continuing influence of the coalition of politico-bureaucrats and corporate interests that pervades the sector, as elsewhere ${ }^{67}$ There are also major questions about the affordability of these programs; many local programs simply fail to deliver the benefits promised to residents, while others have been driven into debt as they fail to keep pace with their commitments.

Such problems suggest that, if we are witnessing the creation of an Indonesian welfare state, it is still in the early stages of what is likely to be a slow process of formation (though, of course, all welfare states took many decades to construct). On the other hand, the apparent breadth of support for social protection policies across a broad range of Indonesia's parties and local politicians suggests that such policies are arising as a result of a powerful political logic. And, indeed, it would be possible to point to many other areas where the logic of electoral competition is reconfiguring policy. The trend to finance public education is virtually identical to that in healthcare, with a rash of initiatives at the center (not least, a constitutional requirement mandating 20 percent of the state budget be spent on education) and in the regions (a proliferation of free-education policies, subsidies, and scholarship schemes). A less obvious example concerns communities in remote rural and forested areas that were long neglected by state development programs (e.g., Dayak communities in Kalimantan) and that now find themselves able to leverage their voting power to

${ }^{66}$ For an excellent overview of such problems, see Elizabeth Pisani, "Medicine for a Sick System," Inside Indonesia 111 (2013), http:/ / www.insideindonesia.org/ write-for-us/ medicine-for-a-sick-system, accessed August 15, 2013.

${ }^{67}$ Andrew Rosser, "Realising Free Health Care for the Poor in Indonesia: The Politics of Illegal Fees," Journal of Contemporary Asia 42,2 (2012): 255-75. 
attract desired development projects that had for decades eluded them: new roads, bridges, community buildings, and the like. Very often these come in the form of "club goods" that are awarded to particular communities by political candidates in exchange for votes; but even if the distribution is clientelistic, such projects are often strongly desired by local communities. Elections have shifted, at least in some places and to some degree, the balance of policy preferences in favor of previously marginalized voters. As a result, even if many occupants of political office are drawn from the same stock as the old New Order elite, some now act according to a new political logic.

\section{Conclusion}

My main interest in making this analysis has not been to advance a new theory of political power and its relationship to material inequality, or to defend an old one, but to provide a more accurate assessment of the influence of popular forces in Indonesian politics. The phenomena described in this essay suggest that when we consider evidence in the form of policy outcomes, some of our assumptions about the political marginalization of lower class interests in Indonesia require modification. I have thus argued for an analysis that places at its center a wider array of social interests than the oligarchs and elites who have consumed so much scholarly attention. In particular, I have argued we should no longer write subordinate groups out of the frame, but, rather, should pay closer attention to the ways that they express themselves politically and, in doing so, challenge, contend with, or are conciliated or incorporated by, oligarchic power. We have become over-used to viewing Indonesia as a site of political domination; it remains equally a place of contestation-in the contentious politics of street protests and social movements that have become central to political life, and in the perpetual frictions that occur between oligarchic, popular, and other interests within arenas like parliaments, parties, and electoral politics. That these struggles are complex, and take place in contradictory and fragmented ways, involving ever-shifting political coalitions and conflicts, reflects the complexity of Indonesian democracy and the kaleidoscopic patterns of social interest that underpin it.

But, setting this basic message aside, does the analysis presented in the preceding pages fundamentally challenge the oligarchy thesis advanced by authors such as Hadiz, Robison, and Winters (even if it disagrees with the empirical assessment they have made so far of the political influence of subordinate groups)? If we interpret that thesis in its most basic form, as a theoretical proposition that links political authority to material wealth, and as an assessment of Indonesian politics that sees oligarchs as disproportionately influential politically, then the answer is no. Both the growing organizational power on the part of labor described above, and the halting emergence of local healthcare schemes, can be compatible with a society marked by extreme inequalities of wealth and, consequently, political power. Arguably, neither phenomenon challenges the core interests of oligarchs, though big business has been generally hostile to demands advanced by workers, and local healthcare programs presumably divert funds from purposes that might more readily be subject to oligarchic capture. But in such a perspective, what phenomena would constitute a true challenge to oligarchy? In Jeffrey Winters's analysis, for example, oligarchy is all but a universal characteristic of contemporary human society, including in countries like Sweden that are normally considered to be exemplars of social-democratic equality. If 
all contemporary capitalist societies are marked by extreme inequalities of wealth, and therefore political influence, it is not surprising that Indonesia should be afflicted by the same malady. Simply recognizing the power of oligarchy in Indonesia, therefore, does not get us very far analytically.

Of course, these authors have gone further than merely making such a basic diagnosis of class power; they also suggest that the character of oligarchic dominance contributes particular features to Indonesia's regime form, and its trajectory. For example, Winters writes of Indonesia as being an "untamed" oligarchy in which oligarchic power is all but unconstrained by mediating political institutions or an impartial rule of law. Oligarchs themselves confront "a proliferation of lateral threats and predation from above," but conditions for other actors are even more subject to the caprice of a system virtually without a rule of law. ${ }^{68}$ Robison and Hadiz have suggested that the reassertion of forces nurtured under the New Order created an "illiberal form of democracy [that is] already consolidated and entrenched." ${ }^{69}$ These authors' works are, to put it bluntly, not optimistic about the prospects for political reform or social progress.

If we broaden our assessment of Indonesia's new democracy in the way suggested in this essay, we may look at some of these issues in a different light. One topic that needs more serious consideration is the consequences of democracy itself for the balance of power between oligarchs and other forces. As Stephan Haggard and Robert Kauffman have suggested, "Democratic politics has long been associated with pressures for redistribution, through mechanisms that are basic, constitutive features of democratic rule itself." ${ }^{70}$ These mechanisms include not only the opening of democratic space for organization and mobilization of lower class interests, but also electoral competition itself and its placing of "institutionalized uncertainty" at the heart of political life. ${ }^{71}$ We do not need to adopt an extreme pluralist interpretation to note the many ways in which organizations representing subordinate groups in Indonesia are trying to influence policy outcomes, sometimes with considerable success, and the ways in which traditional politicians, including those with links to oligarchic power, are driven to make policy concessions in order to attract electoral support.

More broadly, the analysis presented in this article suggests the need for a wider reconsideration of the nature of Indonesia's democratic transition, its postauthoritarian dispensation, and its future trajectory. Political contestation and the mobilization of subordinate groups were central to the fall of the Suharto regime. They did not end with the consolidation of Indonesia's current political order. The form of Indonesia's current regime distills many of the goals and achievements of oppositional social movements that were dismissed and marginalized in the period leading to 1998,

\footnotetext{
${ }^{68}$ Winters, Oligarchy, p. 181.

${ }^{69}$ Vedi R. Hadiz and Richard Robison, "Neo-Liberal Reforms and Illiberal Consolidations: The Indonesian Paradox," City University of Hong Kong, Southeast Asia Research Centre Working Papers Series No. 52, 2003, p. 9.

${ }^{70}$ S. Haggard and R. Kauffman, Development, Democracy, and Welfare States (Princeton, NJ, and Oxford: Princeton University Press, 2008), p. 13.

${ }^{71}$ On institutionalized uncertainty, see A. Przeworski, Democracy and the Market: Political and Economic Reforms in Eastern Europe and Latin America (New York, NY: Cambridge University Press, 1991).
} 
just as it embodies new forms of influence for oligarchic forces first incubated under the New Order. Oligarchic power is a critical part of the current political dispensation, but so, too, are continuing efforts by subordinate groups to represent themselves and achieve social goals, as well as efforts by politicians, oligarchic or otherwise, to accommodate at least some of their demands.

The emergence over time of a more liberal democracy, of a more tamed oligarchy, or, indeed, of a more effective welfare state, will depend on the outcomes of such contests, not just of internal conflicts among the wealthy and powerful. In particular, lower class groups are likely increasingly to find that many of the formal victories they achieve through policy concessions and legal reform will amount to very little if not backed up by effective rule of law and consistent implementation. ${ }^{72}$ The achievement of such reform goals in advanced democracies-to the extent that they have been achieved-was typically the product of multigenerational struggles over long time periods. There is every indication this will be the case in Indonesia, too, and plenty of evidence from the first decade of Indonesian democracy that we need not be morbidly pessimistic about the eventual outcome.

\footnotetext{
${ }^{72}$ One specific example concerns severance pay, generous provisions for which were one of the signal achievements of labor activism in the post-Suharto period. Yet one recent report suggests very low compliance, with only a third of workers entitled to severance pay actually receiving it, and workers receiving only about 40 percent of the payments due to them. See Vera Brusentsev, David Newhouse, and Wayne Vroman, "Severance Pay Compliance in Indonesia," World Bank, Policy Research Working Paper 5933, Social Protection Unit, 2012.
} 